\title{
CSÍPŐPROTÉZISEK BERÖGZÜLÉSÉNEK ÉS ÉLETTARTAMÁNAK OPTIMALIZÁLÁSI LEHETŐSÉGE FÉMNYOMTATÁS ÉS MESTERSÉGES INTELLIGENCIA SEGÍTSÉGÉVEL
}

\section{Szerző:}

Szabó Dániel

Magyarország

Szerző e-mail címe:

szabo.danie1995@gmail.com
Lektorok:

Mező Ferenc (PhD)

Eszterházy Károly Egyetem

Mező Katalin $(\mathrm{PhD})$

Debreceni Egyetem

...és további két anonim lektor

\begin{abstract}
Absztrakt
Manapság egyre fiatalabb korosztályok részéről támad igény csípőprotézis beültetésére, azonban a napjainkban alkalmazott csípőprotézisek élettartama véges, amiben fontos szerepet játszik a protézisek kilazulása. Orvosbiológiai kutatások feltárták, hogy a csontszövet képes egy lyukacsos fogadófelületbe belenőni, biológiai kapcsolódást létrehozva azzal, ilyen szerkezeteket pedig a korunkban elérhető additív technológiák segítségével létre tudhatunk hozni. A tanulmány célja egy lehetséges irányt felvázolni az implantátumokat alkotó, additívan gyártható, lyukacsos szerkezetek belső struktúrája, és a szerkezetek mechanikai tulajdonságai között fennálló összefüggések feltárására, és a szerkezetek optimalizálására.
\end{abstract}

Kulcsszavak: csípőprotézis, élettartam növelés, additív technológiák, fémnyomtatás, mechanikai tulajdonságok, mesterséges intelligencia

Diszciplina: orvostudományok, műszaki tudományok, informatikai tudományok, matematikai tudományok

\footnotetext{
Abstract

OPTIMIZATION POSSIBILITY OF THE FIXATION AND LIFESPAN OF HIP PROSTHESES WITH THE USE OF METAL ADDITIVE MANUFACTURING AND ARTIFICIAL INTELLIGENCE

Nowadays, there is a demand for hip implants by younger and younger age groups, but the lifespan of the hip prostheses used today is finite, in which the loosening of prostheses plays an important role. Biomedical research has revealed that bone tissue can
} 
infiltrate a porous receiving surface, creating a biological connection with it, and such structures can be created using additive technologies available in our time. The aim of this study is to outline a possible direction for exploring the connection between the internal structure, and the mechanical properties of additively manufacturable porous structures, and the possibilities of their optimization.

Keywords: hip implant, additive technologies, metal additive manufacturing, lifespan elongation, mechanical properties, artificial intelligence

Disciplines: medicine, engineering, informatics, mathematics

Szabó Dániel (2021): Csípőprotézisek berögzülésének és élettartamának optimalizálási lehetősége fémnyomtatás és mesterséges intelligencia segítségével. Mesterséges intelligencia interdiszciplináris folyóirat, III. évf. 2021/1. szám. 73-85. doi: 10.35406/MI.2021.1.73

A leggyakoribb felnőttkori csípőbetegségek az ízületi kopás, és a csontelhalás jelenségekre vezethetôk vissza. Az ízületi kopás egy természetes folyamat, melynek során az idő előre haladtával a csontok végét borító porc károsodik, a csont elhalás folyamata során pedig vérellátási zavarból kifolyólag felpuhul a porc alatti csontvég, majd idôvel beszakad (Net1). A pácienseknél ezen problémák állandósult fájdalom és mozgáskorlátozottság formájában szoktak jelentkezni, és ez esetben az orvosok általában protézis beültetését javasolják (Net2). A beavatkozás iránt egyre fiatalabb korosztályok részéről támad igény, a hagyományos implantátumok élettartama viszont véges. Amikor egy implantátum tönkremegy, revíziós mútétet szükséges végrehajtani, mely az eredeti mútétnél megterhelőbb a beteg számára, így felmerült az igény új típusú, hosszabb élettartammal rendelkező protézisek kifejlesztése iránt. A legrégebben alkalmazott implantátumok egy tömör szárral kerülnek beépítésre a combcsontba, cementes rögzí- téssel (Net3). Ezen implantátumoknál gyakran megfigyelhető az a jelenség, hogy az implantátum átveszi a terhelést a környező csontszövetekről, melyekben idővel így csontritkulás alakul ki, és ez végül az implantátum kilazulásához vezet (Huiskes, 1993). Kutatások kimutatták, hogy a csontszövet képes belenőni egy meghatározott méretű pórusokkal rendelkező fogadófelületbe (Naoya és tsai, 2016), amit hogyha sikerül a csípőimplantátumoknál alkalmazni, megoldható lehet a kilazulás problémája. Ezen ismeretek alapján kifejlesztésre kerültek különféle porózus bevonatokkal ellátott protézis szárak, amelyek nagymértékben javítottak a berögzülésen, ugyanakkor több probléma is felmerült velük kapcsolatban, úgymint a nem egységes pórusméret, az esetenként túl vékony rétegvastagság, vagy a bevonat bizonyos idô utáni károsodása, leválása. (Ibrahim és tsai, 2015) Napjainkban már elérhetővé vált a fémnyomtatás technológiája kellően finom gyártási pontossággal, melynek segítségével akár 
egész protézisek legyárthatók lehetnek egy darabban, tervezhető, meghatározott nagyságú pórusokkal, az ezzel készített implantátumok pedig felválthatják az utólagos bevonattal ellátott protéziseket. A tanulmányban bemutatásra kerül, hogy napjainkban milyen 3D fémnyomtatási eljárások léteznek, és azokat milyen célokra, milyen eredményekkel használták fel eddig, majd bemutatásra kerül néhány 3D tervezőprogram segítségével létrehozott, fémnyomtatással legyártható, lyukacsos próbatest, és felvázolásra kerül egy irány, melynek segítségével kategorizálni lehetne mesterséges intelligencia segítségével, hogy a szerkezet belső kialakításának változtatása milyen hatással van a szerkezet mechanikai tulajdonságaira, ami által optimalizálni lehetne az implantátumok élettartamát.

A tanulmány alapját részben egy korábbi, saját TDK dolgozat képezi, melyhez különböző gondolatok kerültek hozzákapcsolásra.

\section{Additív megmunkálás}

1981-ben a Texasi Egyetem Műszaki Karán Carl Deckard, Joe Beaman és Paul Forderhase kifejlesztették a Szelektív Lézer Szinterezés folyamatát. Az általuk létrehozott eljárás számítógéppel vezérelt lézersugarakat használt por állapotú részecskék rétegenként történő egymásba olvasztásához. Hármójuk munkája alapján, és a kifinomult számítógépes tervező programok (3D CAD) létrejöttével megszületett az Additív Megmunkálás iparágazata. Az AM korunkban még egy új technológia, megjelenése az elmúlt 30 évre vetítve nagy áttörésnek számít a megmunkálási technológiák területén. Az anyagfelhalmozás módszerén alapszik, a komponensek fokozatos anyaghozzáadással, rétegről rétegre készülnek el az eljárás során (Lian és tsai, 2017; Bill és tsai, 2015).

A technológia az elmúlt 20 évben nagyon gyorsan fejlődött, és mára már több eljárást is magába foglal, mint például a Gyors Prototípuskészítés, a Szabadformájú Szilárdtest Gyártás, vagy a 3D Nyomtatás. Az AM manapság fokozatosan kezd a legfőbb megmunkálási technológiává válni, folyamatosan növekvő sikere a hagyományos megmunkálási módokhoz képest mutatott előnyeinek tudható be, mint például a nagyobb szabadság nyújtása az innovatív tervezés számára, a strukturális komplexitás lehetősége anyagi többlet terhek nélkül kis méretekben is, a szerszámköltségek potenciális eliminálása, a közvetlen megmunkálási folyamat öntőformák nélkül, a gyártási folyamatok lépéseinek eliminálása, vagy a környezetbarátság. A technológia előnyeit jelenleg ellensúlyozza a lassú gyártási folyamat, a magas alapanyagköltség, a limitált komponens méret, a maradó feszültségek kiszámíthatatlansága, és az esetleges utókezelések szükségessége (Krawczak, 2015; Thomas és tsai, 2016; Kumar és tsai, 2015).

A technológia folyamatos fejlődésével kiterjed több különböző területen belüli alkalmazásra is, és tökéletesen beilleszkedik a numerikus tervezés és a gyártási folyamatok láncába. A Gyors Prototípuskészítési technológiák fejlődése miatt lehetségessé vált sorozatgyártás előtt mintadarabok létrehozása nagyon rövid idő alatt. A Mérnöki Visszafejtéssel 
együtt nagyon jól kiegészítik egymást munkadarabok javításában, vagy reprodukciójában. Az elmúlt években a repülőgépgyártás, az autóipar, és az orvosi felhasználás voltak a technológia elsődleges húzóágazatai (Gardan, 2016). A technológia segítségével létrehozhatók prototípusok, kreatív bemutatódarabok, személyre szabott, egyedi használati tárgyak, vagy egyedi tulajdonságokkal bíró orvosi implantátumok is.

A fémek megmunkálására alkalmas AM technológiák elsődleges alkalmazási területei és húzóágazatai a repülőgépgyártás, az olaj és gázipar, a hajóipar, és az autóipar, de a technológia ígéretesnek bizonyul az ortopédiai implantátumok gyártásának területén is.

Bármilyen fémnyomtatás esetén a procedúra két legfőbb paramétere az, hogy milyen nyersanyagból, és milyen energiaforrás segítségével hozzuk létre a terméket. A felhasznált nyersanyag lehet fémpor, vagy huzal. Huzal alapanyag esetén lézer/elektronsugár, vagy ív is használható energiaforrásként. A fémnyomtatásra alkalmazható AM technológiák három fô csoportja a Porágyfúzió (PBF) alapú technológiák, az Irányított Energiaközlés (DED) alapú technológiák, melyek tovább bonthatók a felhasznált energiaforrás alapján, és a sugaras (JET) technológiák (lásd: 1. táblázat - Szabó, 2018).

A porágyfúzió alapú technológiák esetén minden egyes porréteg szelektíven kerül fuzionálásra egy energiaforrás, például lézer segítségével. Ezek a legígéretesebbnek tûnő $\mathrm{AM}$ technológiák kisméretű, kis darabszámú, komplex, fémes munkadarabok gyártásához.
1. táblázat: fémnyomtatási eljárások csoportositása (forrás: a Szerzoó)

\begin{tabular}{|c|c|c|}
\hline $\begin{array}{c}\text { Porágyfúzió } \\
\text { (PBF) }\end{array}$ & $\begin{array}{l}\text { Irányított } \\
\text { energia- } \\
\text { közlés } \\
\text { (DED) }\end{array}$ & $\begin{array}{c}\text { Sugaras } \\
\text { technoló- } \\
\text { giák (JET) }\end{array}$ \\
\hline $\begin{array}{l}\text { Szelektív lézer } \\
\text { szinterezés/olvas } \\
\text { ztás (SLS/SLM) }\end{array}$ & $\begin{array}{l}\text { Mérnöki } \\
\text { lézeres } \\
\text { hálózás } \\
\text { (LENS) }\end{array}$ & \multirow{3}{*}{$\begin{array}{c}3 \text { dimenziós } \\
\text { nyomtatás } \\
\text { (3DP) }\end{array}$} \\
\hline $\begin{array}{l}\text { Fém direkt lézer } \\
\text { szinterezés } \\
\text { (DMLS) }\end{array}$ & \multirow{2}{*}{$\begin{array}{l}\text { Irányított } \\
\text { fémlerakás } \\
\text { (DMD) }\end{array}$} & \\
\hline $\begin{array}{l}\text { Elektronsugaras } \\
\text { olvasztás (EBM) }\end{array}$ & & \\
\hline
\end{tabular}

Szelektiv lézer szinterezéssel (Singh és tsai, 2017; Olakanmi és tsai, 2015) könnyűszerkezetű, porózus struktúrák gyárthatók. Ezeknél lehetséges a végtermék súlycsökkentése a várható igénybevételre való tervezéssel, így tovább csökkenthető az alapanyag-szükséglet, illetve a mérgező kemikáliák és hűtőanyagok felhasználása is (Buchbinder és tsai, 2012; Cooper és tsai, 2012). A technológiának természetesen hátulütői is vannak. Egy ilyen eljárással készült terméknek rossz a felületi minôsége, az alaki pontossága, és az anyagi tulajdonságai (mikrostruktúra és mechanikai tulajdonságok). Az ilyen jellegű elvárásokban egy SLM technológiával készült termék nem teljesíti az ipari felhasználhatósághoz szükséges elvárásokat. Ezen hátrányok kiküszöbölésére utókezelések (polírozás, festés, hőkezelés (Net4)) alkalmazása szükséges, de ezzel a gyártási folyamat 
meghosszabbodik, és annak költségei növekednek. A 2000-es évek elején kutatásokat végeztek porózus biomedikai struktúrák létrehozására, melyek során szempont volt az elégséges mechanikai tulajdonságok megtartása. Egy tanulmányban porózus SS-316L anyagot készítettek SLS technológiával. Az eredményeik szerint 1100-1300 fok közötti hőmérsékleten szinterezés után a termékek mechanikai tulajdonságai nagyban javultak. Felismerték, hogy a mikroszerkezeti paraméterek és a mechanikai tulajdonságok a szivacsos csontszerkezet tulajdonságaihoz hasonlóra állíthatók optimalizált gyártási paraméterekkel, és a szinterezési hőmérséklet megfelelő beállításával (Singh és tsai, 2017; Xie és tsai, 2013). Kiderült az is, hogy az SLS technológiával gyártott, megerősített kompozit bio-elemek kristályosak, bioaktívak és oszteokonduktívak, melyek nagyon kedvező tulajdonságok a csontbenövés elősegítéséhez (Singh és tsai, 2017; Xiaohui és tsai, 2015). Az SLS/SLM technológiát már többen alkalmazták orvosi felhasználású implantátumok létrehozására (Stoodley és társa, 1996; Hayashi és társai, 2005). A technológiával 20 mikrométeres rétegvastagság is elérhető. (Net5)

A fém direkt lézer szinterezés fémport, és egy nagy energiájú lézert használ, hogy szinterezés útján létrehozzon egy terméket. Az eljárás nagymértékben hasonlít az SLS/SLM technológiákhoz, de eltérő technológiai paraméterekkel üzemel. Az SLS/SLM polimereket, vagy bevonatos fémporokat, míg a DMLS bevonatmentes, előre ötvözött fémporokat használ a szinterezés alapanyagaként. Egy egyedi Ti-6Al-4V ötvözetből, DMLS eljárással készült kondiláris lemez geometriájának megvizsgálták a mechanikai szilárdságát és pontosságát szakítószilárdság és mikro-keménységmérésekkel, illetve ANSYS szoftverrel is. Az eredmények azt mutatták, hogy a DMLS technológia széles körben alkalmazható koponya és állcsont implantátumok készítéséhez az eljárás során elérhető kedvező mechanikai tulajdonságok miatt. Egy további képfeldolgozó szoftver igazolta az eljárás alkalmazhatóságát emberi állcsontokban is (Singh és tsai, 2017; Gregolin és tsai, 2013). Állatkísérleteket végeztek nyulakon, melyek azt mutatták, hogy azok combcsontjába beépítve az állati csontszövet behatolt az implantátum pórusaiba, és közvetlenül hozzákötött annak falaihoz 12 héten belül (Singh és tsai, 2017). Egy tanulmányban DMLS procedúrával készült, Ti-6Al-4V termékeken végeztek maradó feszültségre vonatkozó vizsgálatokat. A termékek EOSINT M280 géppel készültek az EOS által javasolt gyártási paraméterek használatával. A maradó feszültségeket elemezték, megvizsgálták a mikrostruktúrát, illetve a fö feszültségek nagyságát és irányát is. Arra az eredményre jutottak, hogy gyártás után az xy síkban kéttengelyű húzófeszültségek maradtak vissza, és a fő komponens a szkennelési iránynyal egytengelyű volt (Zyl és tsai, 2016). A technológiával akár 20 mikrométeres rétegvastagság, és 250x250x325 mm nagyságú munkatér méret is elérhető. (Net6)

$\mathrm{Az}$ elektronsugaras olvasztás egy nagy energiájú elektronsugarat használ energiaforrásként, melyre kiemelkedő pontosság és nagy olvasztóképesség jellemző, ami nagy produktivitást eredményez. Egy tanulmányban új- 
szerű, celluláris Ti-6Al-4V struktúrákat készítettek ortopédiai felhasználásra EBM technológiával. Számítógépes tesztek eredményeképp demonstrálták, hogy az EBM technológia alkalmas összekapcsolt porozitással rendelkező 3D struktúrák létrehozására. Ez a szerkezet alkalmas szövet benövesztésre és eresítésre (Singh és tsai, 2017; Heinl és tsai, 2008). Egy tanulmányban Ti-24Nb-4Zr-8Sn komponenseket készítettek maximum 70\% porozitással, és öregítő eljárásnak tették ki óket. Az ilyen anyagból, EBM eljárással készített komponensek körülbelül kétszeres erőmodulusz arányt mutattak Ti-6Al-4V anyagból készült komponensekhez képest, azonos porozitás mellett. A technológiával 20 mikrométeres rétegvastagság érhető el. (Singh és tsai, 2017; Liu és tsai, 2016; Szabó, 2018).

Az irányitott energiaköolés alapú technológia egy komplex nyomtatási folyamat, melyet általában javításokhoz, vagy meglévő alkatrészekhez való anyaghozzáadáshoz használnak. A DED a fémmegmunkálásban kevésbé terjedt el teljes termékek AM-jéhez, elsősorban a kisebb pontosság és a szükséges utómegmunkálások miatt.

A mérnöki lézeres hálóáast azért fejlesztették ki, hogy fém alkatrészeket tudjanak segítségével gyártani közvetlenül a CAD modellek alapján. Az eljárás során fémport juttatnak egy olvadt medencébe, illetve a javítani kívánt munkadarab nagy energiájú lézersugár segítségével megolvasztott felületébe (Julien, 2016). A többi, por ágyat használó technológiához képest lényegesen nagyobb méretű munkadarabokat lehet legyártani az eljárás segítségével (Net7). Egy tanulmányban Ti-TiO2 alapú új struktúrákat készítettek funkcionális osztályozás útján LENS technológia alkalmazásával. Ezek a funkcionálisan osztályozott struktúrák változó TiO2 kerámia koncentrátumot tartalmazva biokompatiblisnek, és nem mérgezőnek bizonyultak, illetve javították a keménységét, felületi nedvesítőképességét és formációját a kemiszorbeált kenőanyag filmeknek. Ezek az egységesített struktúrák egyik felületükön nyílt porozitással, a másikon alacsony súrlódással megszüntethetik a tehertartó implantátumok többféle anyagból, több komponensből történő felépítésének szükségességét, például teljes csípő protézisek esetén (Singh és tsai, 2017; Balla és tsai, 2009).

Az irányitott fémlerakás egy fémpor injektáló rendszeren alapul, melyhez egy szálas lézer társul egy robotkaron. A folyamat rendkívül hasonlít az FDM technológiához, mert a fúvóka mozgás közben helyezi le az olvasztott fémet (Net8). A DMD nagyon jól használható meglévő szerszámok javításához, már meglévő nagy munkadarabokhoz további részek építéséhez, vagy akár új termékek létrehozásához is. Elsősorban a repüléstechnikában alkalmazzák komplex és drága részegységek javításához azok pótlása helyett (Szabó, 2018).

A 3 dimenziós nyomtatás segítségével fém munkadarabok is gyárthatók. Az eljárás során az elérhető rétegvastagság kb. 90 
mikrométer. A Prometal egy 3D nyomtatási folyamat, mely rozsdamentes acélporból dolgozik. A nyomtatási folyamat során egy folyékony kötőanyagot lövellnek sugarakban az acélporra. A folyamat végén szükséges egy utókezelés, ennek során szilárdul meg teljesen az anyag. A Digital Metal ${ }^{\mathrm{TM}}$ egy precíziós tintasugaras technológia, amit a Svéd Fcubib AB fejlesztett ki, mely 3DP eljárással hoz létre mikro fém komponenseket $20 \mu \mathrm{m}$ felbontásban, és kb. $4 \mu \mathrm{m}$ felületi érdességgel (Johander és tsai, 2007; Johander és tsai, 2005; Szabó, 2018).

Az irodalomkutatás alapján az EBM, és a DMLS technológia segítségével egyaránt készítettek már orvosi implantátumokat, ezen technológiák ígéretesnek bizonyul-hatnak ortopédiai alkalmazásra (Szabó, 2018).
Az EBM eljárással általában kisebb méretú munkadarabok készíthetők, míg a DMLS technológia munkaterének mérete alkalmas lehet akár egy teljes csípőprotézis egy darabban történő legyártására is.

\section{Próbatest minták}

A tanulmányhoz szabványos próbatest modellek készültek (lásd: 1. ábra). A próbatestek egységcellákból, többféle kialakításban, az ISO 13314 szabvány (Net9) és az orvosbiológiai elvárások alapján lettek létrehozva nyomóvizsgálatok végzéséhez. Mindhárom próbatest $10 \mathrm{~mm}$ átmérōjü, és $\mathrm{kb} .15 \mathrm{~mm}$ magasságú henger, ezek közül kettő eltérő kocka egységcellákból, egy pedig oktaéder egységcellákból lett felépítve (lásd: 2. táblázat).

1. ábra: $A, B, C$ próbatestek. (forrás: a Szerzố)
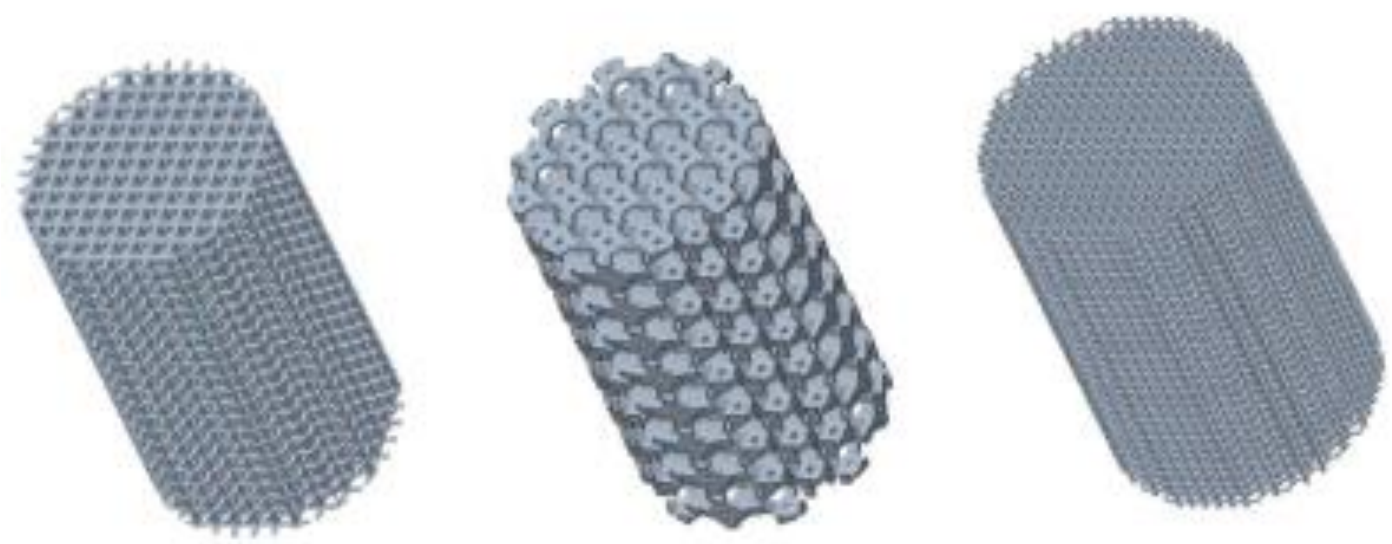
2. táblázat: a próbatestek adatai. (forrás: a Szerzó)

\begin{tabular}{|l|l|l|l|}
\hline \multicolumn{4}{|c|}{ A próbatestek adatai } \\
\hline Megnevezés & Próbatest A & Próbatest B & Próbatest C \\
\hline Egységcella típusa & Kocka & Oktaéder & Kocka \\
\hline Befoglaló méret & $0,8^{*} 0,8^{*} 0,8 \mathrm{~mm}$ & $2 * 2^{*} 2 \mathrm{~mm}$ & $0,5^{*} 0,5^{*} 0,5 \mathrm{~mm}$ \\
\hline Gerendavastagság & $0,2 \mathrm{~mm}$ & $0,4 \mathrm{~mm}$ & $0,1 \mathrm{~mm}$ \\
\hline
\end{tabular}

A próbatestek anyagtulajdonságinak meghatározása során nagyon fontos figyelmet fordítani arra, hogy humán felhasználásra csak biokompatiblis, nem mágnesezhető anyagok alkalmazhatók, ilyen például a DMLS eljárásban használható titán ötvözet (Ti-6Al-4V) (lásd: 3. táblázat), az egységcellák tervezése során pedig figyelembe kell venni, hogy a csont benövéséhez a 600 mikronos pórusméret a legoptimálisabb (Wang és tsai, 2017).

\section{3. táblázat: a titán ötvözet anyagtulajdonságai} (forrás: Mankovits, 2018 alapján a Szerzó)

\begin{tabular}{|l|c|}
\hline \multicolumn{2}{|c|}{ Az alapanyag tulajdonságai } \\
\hline Anyagtípus & Titán ötvözet \\
\hline Jelölés & Ti6Al4V \\
\hline Szakítószilárdság & $1075 \mathrm{MPa}$ \\
\hline Folyáshatár & $965 \mathrm{MPa}$ \\
\hline Rugalmassági modulusz & $114,5 \mathrm{GPa}$ \\
\hline Poisson tényező & 0,34 \\
\hline
\end{tabular}

\section{A próbatestek létrehozása}

A modellek a PTC Creo Parametric programmal lettek létrehozva. A program segítségével lehetséges különböző alapgeometriák egységcellákból való felépítése a „Lattice” funkció segítségével. (lásd: 2. ábra) A Lattice egy parametrizálható funkció, lehetséges többek között változtatni a dimenziók számát (23D), a kitöltés módját, az egységcellák típusát és méreteit, az egységcellákon belül a gerendák elhelyezkedését és vastagságát, és a gerendák keresztmetszetének alakját is (Szabó, 2018).

\section{Vizsgálati eljárás}

Az egyes próbatestek statikus igénybevételre vonatkozó mechanikai tulajdonságai meghatározhatók például egy nyomóvizsgálat segít ségével, melynek során az egyes próbatesteket két sík közé helyezzük, majd a síkokat egymáshoz közelítjük (3.ábra).

2. ábra: az alkalmą̧ató egységcellák (forrás: a Szerző)

3. ábra: a nyomóvizsgálat vázlata (forrás: Szakács és tsai, 2012)

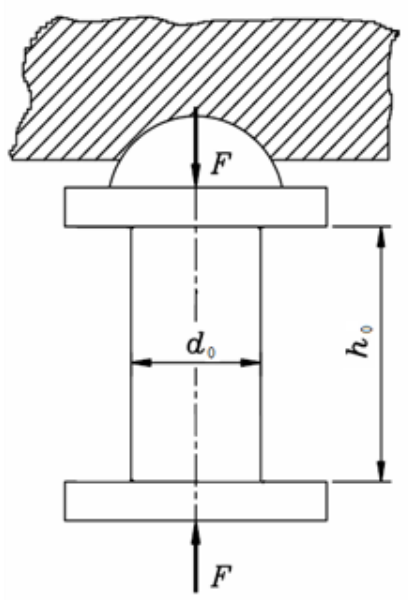

A vizsgálat során szenzorokkal mérhető az összenyomódás, és a kifejtett erő értéke, melynek alapján felrajzolható a próbatest erôelmozdulás görbéje, illetve feszültség-nyúlás görbéje, ezekből pedig meghatározható a próbatest több mechanikai tulajdonsága, mint például a folyáshatár, a nyomószilárdság, a merevség, és a rugalmassági modulusz.

A vizsgálat szimuláció segítségével is elvégezhetô a rugalmas alakváltozási tartományban, ahol ezek a görbék lineárisak. Egy FEMAP program segítségével végzett szimuláció során legelőször egy egységnyi, 0,001 mm-es elmozdulás kerül előírásra kalibráció végett, ami alapján kiolvasható, hogy ez esetben a geometriában mekkora a legnagyobb ébredő feszültség, majd a linearitás miatt meghatározható az, hogy hány milliméter elmozdulást kell előírni ahhoz, hogy a geomet- riában a megengedhetô maximális feszültség ébredjen. A kapott értékkel lefuttatható egy újbóli szimuláció, melynek végeredményeképp kiolvasható, hogy kritikus terhelésnél mekkora erő terheli a próbatest felső lapját. Az így kiolvasott erő, és az előírt elmozdulás értékek alapján felrajzolható a próbatest erőelmozdulás görbéje (Mankovits, 2018; Szabó, 2019).

\section{Szerkezetoptimalizálás mesterséges intelligencia segítségével}

Mivel a próbatestek (lásd: 1. ábra) parametrikusan változtatható egységcellákból (lásd: 2 . ábra) épülnek fel, ezért lehetséges az egyes paraméterek egy-egy inkrementummal való megváltoztatása, és minden egyes változtatás hatásának megvizsgálása a teljes próbatest mechanikai tulajdonságaira. Az összes paraméter egyenként, lépcsőzetesen történő változtatásával rendkívül nagy darabszámú modellt hozhatunk létre és vizsgálhatunk meg, ez az adatmennyiség pedig alkalmas lehet egy mesterséges intelligencia betanítására. A mesterséges intelligencia a makro méretben azonos, szabványos próbatesteken lefolytatott betanulás után alkalmas lehet más, komplex geometriák esetében is meghatározni, hogy adott mechanikai elvárás, illetve adott feltételek (például meghatározott felületi pórusméret) együttes teljesítésére milyen szerkezeti kialakítás lehet a legoptimálisabb.

A tanulási folyamat elvégezhetô szimuláció, vagy valódi vizsgálat segítségével is, de a magas darabszám miatt az anyag és gépköltségek megspórolása végett érdemesebb lehet szimulációkat végezni. Megfelelő informatikai hát- 
térmunka segítségével az inkrementálisan változtatott próbatestek automatizáltan létrehozhatók, és végeselemes szimulációs szoftverbe betáplálhatók, analizálhatók lehetnek, melyekból az MI önállóan kinyerheti a betanuláshoz szükséges adatokat, létrehozhat egy adatbázist, és később ezen adatbázis alapján hozhat döntéseket komplex geometriák adott terheléshez igazított, optimális mikro szerkezeti kialakításának meghatározásában.

A folyamat akár alkalmas lehet a mikro szerkezeti kialakítás, és a teljes próbatestek makro méretbéli mechanikai tulajdonságai közötti pontos matematikai összefüggések feltérképezésére is.

Az élettartam a statikus mechanikai tulajdonságok mellett nagyban függ a protézisek esetén ismétlődően fellépő terhelések miatt a szerkezet kifáradásnak való ellenállásától is. Ennek meghatározása általában valódi fárasztóvizsgálattal történik, mely alatt jelen esetben a komplett, szerkezetileg optimalizált, kinyomtatott csípőprotézis fárasztóvizsgálatát kell érteni. A mesterséges intelligencia ebbe a folyamatba is bevonható lehet a betanult adatbázis alapján, hiszen egy olyan feladatról van szó, mely során adott feltételek teljesítése mellett kell maximalizálni a kifáradási határt (Net10).

\section{Konklúziók}

Megnövelt élettartamú csípőprotézisek kifejlesztésén a világ több tájáról dolgoznak kutatók, ugyanakkor a feladat a mai napig nagy kihívást jelent a tudomány számára, mert ez a terület nagy hardver, szoftver, és inter- diszciplináris tudásbázis igénnyel rendelkezik. Az már bizonyított, hogy a csont bele tud nőni egy lyukacsos fogadófelületbe, és az is bizonyított, hogy milyen lyukacs/pórusméret esetén optimális ez a folyamat, ugyanakkor porózus szerkezetû implantátumok orvosbiológiai elvárásoknak megfelelően történő legyártása, és az ilyen implantátumok élettartama körül még sok kérdés nem került megválaszolásra. Jelen munka felvázol egy irányt, ami mentén mesterséges intelligencia bevonásával a mechanikai tulajdonságokkal szoros összefüggésben álló élettartamot, és annak növelését célzó kérdésekrôl pontosabb képet kaphatunk.

\section{Köszönetnyilvánítás}

A dolgozat elkészítését az EFOP-3.6.1-162016-00022 számú projekt támogatta. A projekt az Európai Unió támogatásával, az Európai Szociális Alap társfinanszírozásával valósult meg.

\section{Irodalom}

Balla VK, DeVasConCellos PD, Xue W, Bose S, Bandyopadhyay A (2009). Fabrication of compositionally and structurally graded $\mathrm{Ti}-\mathrm{TiO} 2$ structures using laser engineered net shaping (LENS). Acta Biomater. 2009 Jun;5(5): p. 1831-7.

DOI 10.1016/j.actbio.2009.01.011

Buchbinder, D., Schleifenbaum, H., Heidrich, S., Meiners, W. \& Bultmann J. (2012). High power selective laser melting 
(HP SLM) of aluminium parts. Physics procedia of the sixth international WLT conference on lasers in manufacturing, vol. 12A, Munich ICM, Germany; 2012. p. 271-8. DOI 10.1016/j.phpro.2014.08.177 Cooper DE, Stanford M, Kibble KA, Gibbons GJ. (2012). Additive manufacturing for product improvement at Red Bull Technology. Mater Des 2012;41: p. 226-30. DOI 10.1016/j.matdes.2012.05.017 E.O. Olakanmi,E.O., Cochrane, R.F. \& Dalgarno, K.W. (2015). A review on selective laser sintering/melting (SLS/SLM) of aluminium alloy powders: Processing, microstructure, and properties. Progress in Materials Science 74 (2015) p. 401-477. DOI 10.1016/j.pmatsci.2015.03.002

Gardan, J. (2016). Additive manufacturing technologies: State of the art and trends. International Journal of Production Research, 2016 Vol. 54, No. 10, 3118-3132. DOI 10.1080/00207543.2015.1115909

Gregolin RF, Barbosa FM, da-Rocha TL, deCamargo Zavaglia CA, Tokimatsu RC. (2013). Development and mechanical characterization of a mandibular prosthesis in titanium alloy fabricated by direct metal laser sintering (DMLS) Proceedings of 22nd international congress of mechanical engineering. 2013.

Hayashi T, Maekawa K, Tamura M, Hanyu K. (2005). Selective laser sintering method using titanium powder sheet toward fabrication of porous bone substitutes.
JSME Int J 2005;A 48(4): p. 369- $75 .$. DOI 10.1299/jsmea.48.369

Heinl P, Muller L, Korner C, Singer RF, Muller FA (2008). Cellular Ti-6Al-4V structures with interconnected macro porosity for bone implants fabricated by selective electron beam melting. Acta Biomater 2008; 4: p. 1536-44. DOI: $10.1016 /$ j.actbio.2008.03.013

Hughes, B. \& Wilson, G. (2015). 3D/Additive Printing Manufacturing: A brief history and purchasing guide. Reston Köt. 75, Kiad. 4, (Dec 2015/Jan 2016): 18-21

Huiskes R. (1993). Stress shielding and bone resorption in THA: clinical versus computer-simulation studies. Acta Orthop Belg. 1993;59 Suppl 1:118-29. PMID: 8116386.

Eldesouky, I., Abdelaal, O. \& El-Hofy, H. (2015). Femoral Hip Stem with Additively Manufactured Cellular Structures. 2014 IEEE Conference on Biomedical Engineering and Sciences (IECBES), 2014, pp. 181-186, DOI 10.1109/IECBES.2014.7047482

Johander, P., Eberhard, W., Necula, D., Haasl, S., \& Jung, E. (2007). Threedimensional electronics packaging and interconnection. 3D PACK. 4M Cross Divisional Report. Cardiff University, Cardiff. pp. 8-22. DOI 10.1007/s00170012-4605-2

Krawczak, P. (2015). Additive Manufacturing of plastic and polymer composite parts promises and challenges of 3D printing. eXPRESS Polymer Letters Vol.9, No.11 
(2015) 959. DOI

10.3144/expresspolymlett.2015.86

Lian Chen, Yong He, Yingxin Yang, Shiwei

Niu, Haitao Ren (2017). The research status and development trend of additive manufacturing technology. Int $J A d v$ Manuf Technol (2017) 89:3651-3660. DOI 10.1007/s00170-016-9335-4

Liu Y, Li S, Hou W, Wang S, Hao Y, Yang R, és társai (2016). Electron beam melted beta-type $\mathrm{Ti}-24 \mathrm{Nb}-4 \mathrm{Zr}-8 \mathrm{Sn}$ porous structures with high strength-to-modulus ratio. J Mater Sci Technol 2016;32: p. 505-8. DOI 10.1016/j.jmst.2016.03.020

Mankovits, T. (2018). Numerical analysis of unit cell models for orthopedic applications. IOP Conf. Series: Materials Science and Engineering 393 (2018) 012019. DOI 10.1088/1757-899X/393/1/012019

Naoya Taniguchi, Shunsuke Fujibayashi, Mitsuru Takemoto, Kiyoyuki Sasaki, Bungo Otsuki, Takashi Nakamura, Tomiharu Matsushita, Tadashi Kokubo, Shuichi Matsuda (2015). Effect of pore size on bone ingrowth into porous titanium implants fabricated by additive manufacturing: An in vivo experiment. Materials Science and Engineering C 59 (2016) 690-701. DOI 10.1016/j.msec.2015.10.069

Net1: A csípő felnőttkori betegségei.

Letöltés: 2021.03.08. Web: http://www.drkovacsgy.hu/cpg/338225/ A-csipo-felnottkori-betegsegei

Net2: Csípőprotézis. Letöltés: 2021.03.08. Web: http://www.drkovacsgy.hu/cpg/731599/ Csipoprotezis

Net3: A csípőprotézis típusai. Letöltés: 2021.03.08. Web: http://www.drkovacsgy.hu/cpg/955851/ A-csipoprotezis-tipusai

Net4: Rapid manufacturing: overview. Letöltés: 2021.03.17. Web: http://www.csa1.co.uk/discoveryguides/ rapidman/overview.php

Net5: Selective Laser Melting Machine SLM®280 2.0. Letöltés: 2018.11.13. Web: https://www.slmsolutions.com/products/machines/selecti ve-laser-melting-machine-slmr280-20

Net6: EOS M 290 The Additive

Manufacturing System for the Production of Serial Components, Spare Parts and Functional Prototypes Directly in Metal. Letöltés: 2021.03.19. Web: https://www.yield247.com/viewer/1097 /download.pdf

Net7: Laser engineered net shaping. Letöltés: 2021.03.19. Web:

https://en.wikipedia.org/wiki/Laser_engi neered_net_shaping

Net8: Direct Metal Deposition (DMD)

Fabrication Process for Metal 3D Prints. Letöltés: 2021.03.19. Web: https://www.sculpteo.com/en/glossary/ dmd-definition/

Net9: ISO 13314:2011. Mechanical testing of metals - Ductility testing Compression test for porous and cellular metals. Letöltés: 2021.03.19. Web: https://www.iso.org/standard/53669.ht $\mathrm{ml}$ 
Net10: High-level expert group on artificial intelligence. A definition of AI: Main capabilities and disciplines. Letöltés: 2021.05.10. Web:

https://www.aepd.es/sites/default/files/ 2019-12/ai-definition.pdf

Stoodley MA, Abbott JR, Simpson A. (1996). Titanium cranioplasty using 3-D computer modelling of skull defects. $J$ Clin Neurosci 1996;3(2): p. 149-55. DOI: 10.1016/s0967-5868(96)90009-0

Sunpreet Singh, Seeram Ramakrishna, Rupinder Singh (2017). Material issues in additive manufacturing - A review. Journal of Manufacturing Processes 25 (2017) p. 185200. DOI 10.1016/j.jmapro.2016.11.006

Szabó Dániel (2018). A fémnyomtatás lehetőségei az implantátumtervezésben. Gépészmérnöki Kari TDK 2017/18/2/129 http:/ / hdl.handle.net/2437/261625

Szabó Dániel (2019). Egységcellákból felépített próbatest mechanikai vizsgálata. Gépészmérnöki Kari TDK 2019/2020/1/ 141 http://hdl.handle.net/2437/277904 Thomas Duda, T. \& Venkat Raghavan, L. (2016). 3D Metal Printing Technology. IFAC-PapersOnLine 49-29 (2016) 103110. DOI 10.1016/j.ifacol.2016.11.111

Tiwari Sunil Kumar, Pande Sarang, Agrawal Sanat, Bobade Santosh M. (2015). Selection of selective laser sintering materials for different applications. Rapid
Prototyping Journal; Bradford Köt. 21, Kiad. 6, (2015): 630-648. DOI 10.1108/RPJ-032013-0027

van Zyl, I., Yadroitsava, I. \& Yadroitsev, I. (2016). Residual stress in Ti6Al4V objects produced by Direct Metal Laser Sintering. South African Journal of Industrial Engineering December 2016 Vol 27(4), pp 134-141. DOI 10.7166/27-4-1468

Wang Zhonghan, Wang Chenyu, Li Chen, Qin Yanguo (2017). Analysis of factors influencing bone ingrowth into threedimensional printed porous metal scaffolds: A review. Journal of Alloys and Compounds 717 (2017) 271-285 DOI 10.1016/j.jallcom.2017.05.079

XiaoHui S, Wei L, PingHui S, QingYong S, QingSong W, YuSheng S, és tsai. (2015).

Selective laser sintering of aliphatic polycarbonate/hydroxyapatite composite scaffolds for medical applications. Int $J$ Adv Manuf Technol 2015;81: p. 15-25. DOI 10.18063/IJB.v5i1.148

Xie F, He X, Cao S, Qu X. (2013). Structural and mechanical characteristics of porous 316L stainless steel fabricated by indirect selective laser sintering. J MaterProcess Technol 2013;213: p. 838- 43. DOI 10.1016/j.jmatprotec.2012.12.014 